\title{
MANAGEMENT EDUCATION AND SUSTAINABLE DEVELOPMENT PROJECTS
}

\author{
Bojana Ostojić, Ivana Berić, Katarina Pavlović, Milutin Pećić
}

\begin{abstract}
Educons University, Faculty for Project and Innovation Management, Serbia
\end{abstract}

Received: 30 June 2020 Revised: 24 July 2020 Accepted: 27 July 2020

\begin{abstract}
Modern management plays a major role and is relevant in the field of sustainable development, since its applicable knowledge contributes to improving the overall atmosphere of a society. In the development of a country, a society based on effective knowledge is important, as well as on the concept of sustainable development. The concept of sustainable development contributes to the improvement of learning and the establishment of social values based on the knowledge and skills of human resources. Thus, there is a need for planned education and the creation of quality management in order for society to slowly move towards the concept of a learning society. In this sense, the aim of this paper is to examine the extent to which a higher education institution can contribute to the above. The research was conducted at the Educons University, Faculty for Project and Innovation Management PMC in Belgrade. On that occasion, it was concluded that the mentioned faculty is an example of good practice in how to educate young people to think about the future and become managers who adhere to the concept of sustainable development. This paper is intended primarily for leaders of higher education institutions in order to gain some insight into aspects of this topic, as well as students to gain more knowledge about the concept of sustainability implemented in educational institutions, and then the general public.
\end{abstract}

Keywords: Sustainable development, sustainable development projects, modern management, higher education institutions.

\section{INTRODUCTION}

Irresponsible exploitation of natural resources by economic entities has led to pollution of biodiversity in some areas, which inevitably reflected on changes at the global level. The concept of sustainable development refers to balanced economic, social and cultural development aimed at preserving the environment and minimizing harmful effects (Bulatović, Ostojić, \& Pećić, 2019). Thus, future generations are left with the possibility of development and quality progress. The essence of the concept of sustainable development is the correlation of economic development and the environment with respect to the legality of ecological systems (Nadić, 2017). For the purpose of achieving sustainable development, it is of great importance to establish social values based on knowledge and abilities, ie. on creating an educated modern management in order to transform the current society into a learning society. The possibility of overcoming the conflicting relations between the economy and ecology can be solved by consistent monitoring of the principles of the concept of sustainable development and valid implementation of sustainable development projects (Šormaz, 2017). In this sense,

Corresponding author. Email: bojanaostojic2002@yahoo.com

ISSN 2560-4961 (online)

Copyright (C) 2020, The Authors. Published by IPMA Serbia.

This is an open access article under the CC BY-NC 4.0 license (https://creativecommons.org/licenses/by$\mathrm{nc} / 4.0 /)$

doi: $10.18485 /$ epmj.2020.10.1.8 
educated human resources are needed that are competent to properly implement sustainable development projects and implement them in a quality manner. In that sense, faculties, as higher education institutions, are of key importance for educating young people in this direction.

\section{RESEARCH METHODOLOGY}

Sustainable development in the future requires that today's higher education system form young people whose opinion is critically and ecologically developed, people who successfully solve the problems they encounter in the future and who work together to build a new, "green" economy with a positive social system that works in accordance with the concept of sustainable development. These young, educated people need to have an innovative way of thinking and acting, to quickly acquire new knowledge and adjust personal competencies in accordance with the expansion of global development trends (Filipović, 2018). In accordance with the above, the goal of this paper was formed: to examine the extent to which a higher education institution can contribute to the creation of modern, educated management that is competent to manage sustainable development projects. The paper first present a literature review, then continue with the text about empirical research and then continue with the results of the research and the conclusions made on the basis of the above. The research was conducted at the Educons University, Faculty for Project and Innovation Management PMC in Belgrade. The sample consists of 120 students from the mentioned faculty who voluntarily participated in the survey. The research instrument is a survey questionnaire created by the author for the purposes of this paper. The questionnaire contains 10 questions related to the examination to what extent the selected faculty educates its students in the field of the concept of sustainable development and application in the form of projects. Scientific research methods of analysis and synthesis, as well as induction and deduction were used. The research instrument is a survey questionnaire created by the author for the purposes of this paper. The questionnaire contains 10 questions related to the examination to what extent the selected faculty educates its students in the field of the concept of sustainable development and application in the form of projects. Scientific research methods of analysis and synthesis, as well as induction and deduction were used. The research instrument is a survey questionnaire created by the author for the purposes of this paper. The questionnaire contains 10 questions related to the examination to what extent the selected faculty educates its students in the field of the concept of sustainable development and application in the form of projects. Scientific research methods of analysis and synthesis, as well as induction and deduction were used. In this paper, we started from the general hypothesis $\mathrm{H}_{\mathrm{O}}$ : Higher education institutions have a relevant significance in the education of young project management staff in the field of sustainable development projects.

\section{KNOWLEDGE - BASED SOCIETY}

In modern society, the operation of economic entities is based on applicable knowledge, as a basic support and comparative advantage over other entities (Andrevski, 2016). Information, competencies and skills are elements that integrate the increasing economic performance and gain more and more value on the market every day. The education system of our country is slowly adapting to the great changes that have occurred in the 21 st century, although strengthening environmental awareness in the curriculum is a step in the right direction (CEVES, 2018). Relevant changes in the domain of information use occur on a daily basis and are conditioned by the expansion of the information services sector. Thus, employees who possess special competencies and knowledge become an imperative of managers in an effort to achieve a competitive advantage in the market (Nikolić, Marković, \& Grbić, 2019). It is necessary to know how to properly use that knowledge, and without modernized and well-educated management it is not possible to achieve that.

\section{SUSTAINABLE DEVELOPMENT CONCEPT AND PROJECTS}

Since the concept of sustainable development has been widely written and is still being 
written, we will briefly look at this topic in the context of our work. Sustainable development is ensuring the steady quality of the environment for future generations, ie. transfering natural resources to new generations at least in the same amount that the current ones used. We are facing negative consequences due to global warming, and the situation is such that natural resources have been used up to $50 \%$. Expert authors are of the opinion that by 2050 this percentage will increase to as much as $85 \%$ (Dobričanin, Todić, \& Lukić, 2018). In recent decades, we have been facing the fact that the ecosystem in which we live is sinking into a growing and significant crisis. The education of quality management staff, trained to implement sustainable development projects, can help solve this.

Innovation is a necessary part of the functioning of entrepreneurship. Creating new ideas, procedures and processes whose goal is not and cannot be exclusively to increase profits, but also to create some new humanitarian motives such as the creation of new "green" jobs (Nadić, 2017). In recent times, the concept of sustainable development has significantly relied on the theory of ecological modernization, which is based on trust in technological improvement and environmental management, both in the state economy and in the political sphere (Filipović, 2019).

\section{EDUCATION FOR SUSTAINABLE DEVELOPMENT}

The responsibility of universities for the development of a society is not a new concept, but on the contrary - it has existed since the universities themselves. Today, it is interesting to look at this topic from the angle of sustainable development. Namely, an educated individual who acquires quality applicable academic knowledge in this field can greatly help to implement the principles of sustainable development through projects that have positive outcomes in the future. General raising of environmental awareness and education for sustainable development are important predictors of a more successful solution of many problems that have arisen between man and society towards the environment. The education reform initiative to address environmental challenges in the 21st century is relevant to the further future of sustainable development (Pejić, Radivojević, \& Marčeta, 2019).

An important step in implementing the idea of sustainable development in higher education is the creation of the UNECE Strategy for Education for Sustainable Development in Vilnius, in March 2005. The strategy contains five basic goals that form the framework for the proper implementation of the idea of sustainable development in university education. These goals are (Buckles, 2018):

- providing conditions for political, regulatory and operational support to the education process for sustainable development;

- promotion of sustainable development through formal and non-formal learning models;

- adequate and regularly conducted education of professors on this topic;

- providing adequate work tools and materials that support more efficient education on sustainable development and

- constant work on developing research in the field of education for sustainable development.

Partial insights into the existence of ideas of sustainable development in university education in the Republic of Serbia indicate the fact that these processes are in the beginning, but also that there is an obvious need to expand this field, since our country has a rich biodiversity (Tančić, 2018). The modern challenges of the concept of sustainability can be overcome if more young people are educated to implement sustainable development projects. Positive outcomes in the domain of sustainable development should be sought in the knowledge economy, and especially in more adequate education, building a system of creativity and mutual tolerance, which would rest on higher education institutions (Tančić, 2018). Education for sustainable development thus becomes lifelong learning. Education for sustainable development can have two 
segments: theoretical and practical concept. While on the one hand the student youth acquires the necessary theoretical knowledge about the concept of sustainable development and thus creates their own opinion and raises personal environmental awareness, on the other hand it is necessary to be able to apply practically adopted theoretical knowledge. This can be achieved through participation in sustainable development projects, either in their creation or real implementation. Here, a significant role is played by the teaching staff who should motivate their students to take this path and put them in various socially responsible situations in order for their acquired knowledge to gain practical application. Therefore, education for sustainable development must not be implemented in university programs in the form of a separate course or a single subject, it is already necessary to reorganize the existing system and methodology of work that would generally support a sustainable lifestyle (Pejić et al., 2019).

It is evident that in addition to the general goals and tasks of the project manager related to project team management and efficient project implementation, different types of projects insist on different characteristics, competencies and knowledge of the project manager in performing new and complex roles and tasks related to specific types of projects such as sustainable development projects (Jovanović, \& Jovanović, 2018).

\section{RESEARCH RESULTS AND DISCUSSION}

The conducted research aimed to examine the extent to which a higher education institution can contribute to the creation of a modern, educated management that is competent to manage sustainable development projects. For these purposes, the Educons University, Faculty for Project and Innovation Management PMC in Belgrade was selected. We will further show the gender structure of the student respondents. As we will see from Chart 1 , male students make up a percentage of $48 \%$ of respondents, while female students have a slight numerical advantage $-52 \%$.

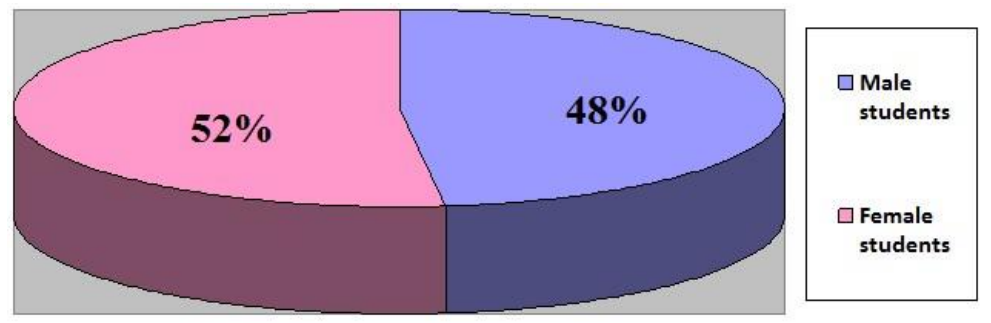

Figure 1: Gender structure of respondents

The first question from the questionnaire was "Does the faculty you attend apply the concept of sustainable development in their programs?" Insight into the answers of the respondents will be given in the form of a table.

Table 1: Respondents' answer to the first question from the questionnaire

\begin{tabular}{|c|c|}
\hline Offered answers & $\begin{array}{c}\text { Percentage of } \\
\text { respondents' answers }\end{array}$ \\
\hline No, it does not apply & $1 \%$ \\
\hline $\begin{array}{c}\text { I am not familiar } \\
\text { with the above }\end{array}$ & $28 \%$ \\
\hline $\begin{array}{c}\text { Yes, it applies in all } \\
\text { forms of work }\end{array}$ & $34 \%$ \\
\hline
\end{tabular}

Yes, it is applied in the form of courses

Thus, the largest percentage of respondents gave a positive answer to the question about the application of the concept of sustainable development at the selected faculty (71\%). However, their opinions (or knowledge) about it are almost divided - a higher percentage of respondents who gave an affirmative answer believe that the concept of sustainable development is implemented in the form of courses in college (37\%), while $34 \%$ recognize the application of this concept in all forms work. This leads us to create the view that the faculty has not yet harmonized and organized the application of the concept 
of sustainable development in all programs, but is still in the domain of individual implementation. The percentage of respondents who are not familiar with the issues raised in the first question is not negligible $(28 \%)$. This fact must be further taken into account since no student should be uninformed about the way of working and implementing the concept of sustainable development, because only in this way can a successful management staff be formed that participates in the future implementation of the principles of sustainable development.

The second question was designed to examine whether the faculty supports activities in support of an environmentally sustainable future. The largest percentage of respondents agreed that the faculty organizes activities of this type $(78 \%)$, the percentage of those who are partially familiar with such activities is $19 \%$, while only $3 \%$ of respondents said they do not know if such activities exist at the faculty.
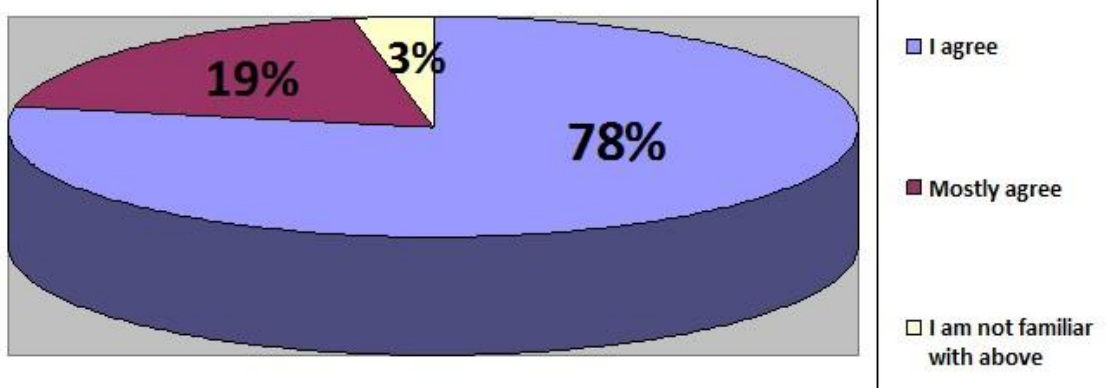

Figure 2: Attitudes of respondents about the activities of the faculty in support of an environmentally sustainable future

In the third question, we examined the attitudes of students about whether they are trained at the faculty to face current and future challenges of sustainable development. Namely, the students answered this question almost completely divided: $48 \%$ of the respondents agree that the faculty provides this possibility, while $50 \%$ of the students stated that they are not sure in which ways it is implemented. $2 \%$ of respondents did not answer this question. This situation unequivocally indicates that the faculty should still work on informing and involving students in this process. The fourth question was "Is the creation of projects on sustainable development organized at the faculty and do you participate in them?", and its goal was to determine the extent to which students are aware of the existence of the faculty and their engagement in that sense.
Table 2: Students' knowledge of the existence of project creation organization and their involvement in it

\begin{tabular}{|c|c|c|c|}
\hline $\begin{array}{c}\text { Offered } \\
\text { answers }\end{array}$ & $\begin{array}{c}\text { Percentag } \\
\text { e display }\end{array}$ & $\begin{array}{c}\text { Offered } \\
\text { answers }\end{array}$ & $\begin{array}{c}\text { Percentag } \\
\text { e display }\end{array}$ \\
\hline $\begin{array}{c}\text { No, it's } \\
\text { not } \\
\text { organize } \\
\mathrm{d}\end{array}$ & $14 \%$ & $\begin{array}{c}\text { No, I did } \\
\text { not have } \\
\text { the } \\
\text { opportunity } \\
\text { to } \\
\text { participate }\end{array}$ & $41 \%$ \\
\hline $\begin{array}{c}\text { I was not } \\
\text { informed }\end{array}$ & $24 \%$ & $\begin{array}{c}\text { I am not } \\
\text { interested } \\
\text { in } \\
\text { participatin } \\
\mathrm{g}\end{array}$ & $12 \%$ \\
\hline $\begin{array}{c}\text { Yes, it's } \\
\text { organize } \\
\mathrm{d}\end{array}$ & $72 \%$ & $\begin{array}{c}\text { Yes, I am } \\
\text { an active } \\
\text { participant }\end{array}$ & $47 \%$ \\
\hline
\end{tabular}


From the data shown in Table 2, we can conclude that a large percentage of respondents $(72 \%)$ were instructed to organize such projects, but that as many as $41 \%$ of the total sample did not have the opportunity to participate in them. Therefore, it is necessary to increase transparency and work on the motivation of students who would participate in such activities (since 12\% of them said they were not interested in participating). The active number of participants is not small -
$47 \%$, but still we need to work on the fact that as many future academic citizens as possible acquire knowledge in this area, because, in the end, they attend a faculty that deals with project management.

The fifth question referred to the determination of student competencies for participation in writing projects on sustainable development.

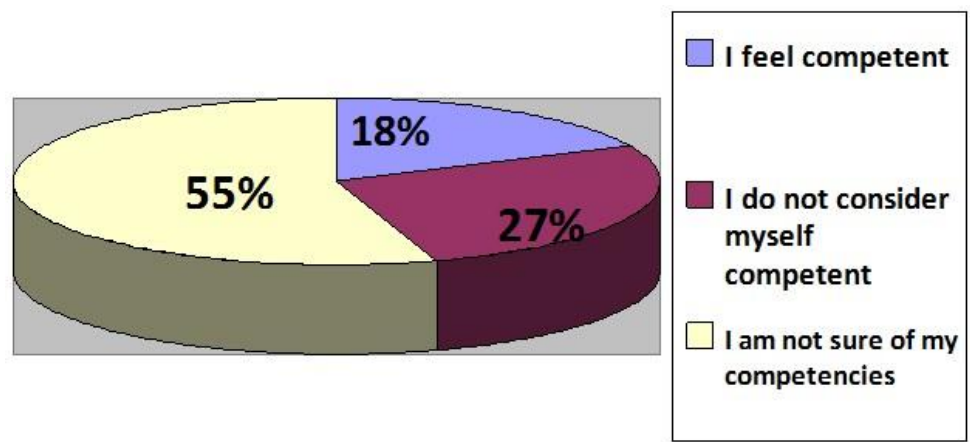

Figure 3: Determining student competencies for participating in writing projects on sustainable development

From the percentage presentation in Graph 3, we see that the largest number of respondents are not sure of their competencies $(55 \%)$. Here we can talk about the role of professors in encouraging students to intensively participate in project tasks, in order to eventually acquire knowledge and skills in this area, master the material and thus be more confident in their skills.

The percentage of those who gave a positive answer is $18 \%$, which is a very small number of respondents, and in the future more appropriate methods and approaches must be considered for those who do not consider themselves competent in this area (27\%).

The sixth question took the form of a supplement and referred to the students' opinion on how they saw the role of modern management within the concept of sustainable development. $12 \%$ of respondents chose to skip this question, which indicates to us the fact that they are not sufficiently versed in this topic. Furthermore, we will give an overview of the highest quality and most interesting answers to the topic of our work. Some of them wrote the following:
- "Modern management must keep pace with trends, both in the field of information and communication technologies that are expanding, and in the field of awareness raising and sharing in accordance with the principles of sustainable development. His role is unambiguous and refers to quality staff who think innovatively and create good solutions in that area."

- "Modern management has a role to play as a driver within the concept of sustainable development. By that I mean that he must always strive for the staff that makes him to think "green" and be familiar with innovations in this field."

- "In order for management to be called modern, it must primarily strive for the knowledge and education of creative individuals who can contribute to a better general economic atmosphere in the country."

We can notice that the students who answered the question (88\%) adopted the knowledge they needed to answer this question, as well as to think in the direction of the future. We can 
hope that they will turn their thoughts into ideas, guided by experts, like their professors.

In the seventh question, we stated that the concept of sustainable development implies favoring knowledge and lifelong learning. From the obtained results shown in Graph 4, we conclude that the largest percentage of students are adequately versed in this topic, and gave the answer that they fully agree with the above statement (85\%). Thus, students have some knowledge of how the concept of sustainable development works and relate it to knowledge and learning as its important segments.

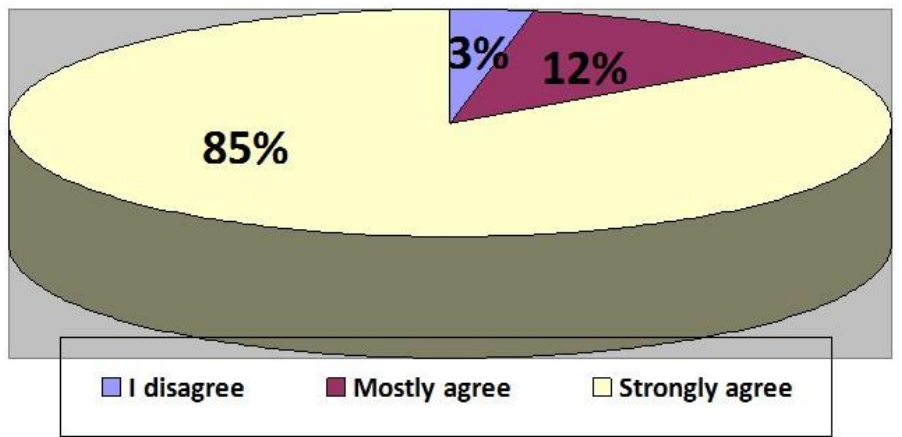

Figure 4: Attitudes of the respondents to the statement made in the seventh question

The next, eighth question aimed to examine the students' opinion on the role of the faculty in education for sustainable development. Unequivocally, their answers indicate that they have a highly formed awareness of the role of education in the concept of sustainable development. Namely, the respondents answered as follows:

- The faculty has a relevant, if not a key role in education for sustainable development $-89 \%$;

- I am not sure what "education for sustainable development" means $8 \%$ and

- I do not think that colleges can play an important role in education for sustainable development $-3 \%$.

Thus, a high percentage of respondents $(89 \%)$ see the importance of the faculty in this concept, but there are also those students who do not understand, are not instructed or sufficiently informed about the meaning of the concept itself. Although it is a small percentage of them - $8 \%$ should definitely work on educating all students in this direction, since young and creative individuals who think effectively and implement the principles of sustainable development are more than necessary for both current and future society.
The penultimate, ninth question was conceived in the form of a statement and read: "Reorganization of the education system is a necessary predictor in achieving sustainability and overall implementation of the model of sustainable development." Respondents' responses are shown in Table 3.

Table 3: Respondents' answers to the ninth question from the questionnaire

\begin{tabular}{|l|c|}
\hline Offered answers & $\begin{array}{c}\text { Percentage of } \\
\text { respondents' answers }\end{array}$ \\
\hline I disagree & $11 \%$ \\
\hline Mostly agree & $27 \%$ \\
\hline Strongly agree & $62 \%$ \\
\hline
\end{tabular}

From the attached data, we conclude that the largest percentage of students understand the importance of this statement (62\%), while partial agreement is expressed by $27 \%$ of the total sample. Those who disagreed had the opportunity to express their opinion in the form of a supplement to this question, and the most interesting answers are the following:

- "I'm not sure how this reorganization can be implemented in today's conditions in our country." 
- "While the entire public of our country is dealing with the Covid-19 virus pandemic, I doubt that those in charge of the education system are thinking about such problems in the long run."

- "It is not possible to carry out the reorganization only at the faculties, without it showing a positive outcome in the future in the concept of sustainable development. Changes are needed in the entire education system in order to continue to bear fruit."

From such student responses, we can conclude that they are not convinced that the education system can be changed in this sense, as well as that those responsible for such reforms have current affairs that limit them from thinking about future moves. Although negative, students' attitudes are very clear and based on the current situation in the education system of the Republic of Serbia.

The last question aimed to examine whether students see themselves as future active actors in modern management and development of sustainable development projects. A large percentage of them point out that they would like to acquire competencies in this area (74\%), some of them do not see themselves in the above (24\%), while a small percentage of them $(2 \%)$ are not sure what that would mean. Thus, we can anticipate the bright future of modern management and active participation in sustainable development projects, as young generations see themselves in this role.

\section{CONCLUSION}

Creating a society based on knowledge, learning and sustainable development refers to encouraging coordination among necessary factors such as greater investment in education in the field of reorganization of the existing system, research, development and practical application of knowledge. A creative individual as part of modern management can be relevant for spreading the ideas of sustainability and implementing sustainable development projects in the future.
From all the above, consulted professional literature and research, we can conclude that the general hypothesis that was used in the research for the purposes of this paper $\mathrm{H}_{\mathrm{O}}$ : Higher education institutions are relevant in educating young project management staff in the field of sustainable development projects, confirmed. Namely, the students gave mostly positive answers to the questions related to the topic, which are in line with the expectations of the authors of this paper. Education and projects for sustainable development are an integral part and basic predictor of management, which is characterized as modern.

Certainly, in the future, it is possible to investigate this topic more widely, in the domain of several higher education institutions on the territory of our country, in order to gain a more complete insight. Also, some of the next steps in future research in this field may be comparisons between the results obtained in this paper and research conducted at other faculties in the country and the region.

\section{REFERENCES}

Andrevski, J. (2016). Održivo ekološko obrazovanje - perspektiva za promenu kulture učenja. Inovacije $u$ nastavi časopis za savremenu nastavu. 29(4), pp. 16-31.

Buckles, J. (2018). Education, Sustainability and Ecological Social Imaginary. Cham, Palgrave Macmillan.

Bulatović, D., Ostojić, B., \& Pećić, M. (2019). Kontradiktornost između ekološke svijesti i djelovanja i potreba suzbijanja ekološkog kriminala. Ecologica. 96, pp. 545-552.

CEVES. (2018). Održivi razvoj Srbije - kako stojimo?. Beograd: Centar za visoke ekonomske studije.

Dobričanin, S., Todić, M., \& Lukić, N. (2018). Prepreke za sprovođenje društveno odgovornog poslovanja u Republici Srbiji. BizInfo (Blace), Časopis Iz Oblasti Ekonomije, Menadžmenta $i$ Informatike. 9(2), pp. 65-80.

Jovanović, P., \& Jovanović, F. (2018). Nove uloge projektnog menadžera. Tehnika Menadžment. 68(2), pp. 270-275. 
Nadić, D. (2017). Ideja preduzetništva i inovacija u kontekstu održivog razvoja. Evropske sveske. 11, pp. 15-19.

Nikolić, B., Marković, S., \& Grbić, A. (2019). Privreda i održivi razvoj u nacionalnim okvirima. BizInfo (Blace), Časopis Iz Oblasti Ekonomije, Menadžmenta $i$ Informatike. 10(1), pp. 85-95.

Pejić, S., Radivojević, R., \& Marčeta, M. (2019). Razvoj strategije obrazovanja za održivi razvoj u Srbiji. XXV Skup Trendovi razvoja: Kvalitet visokog obrazovanja, Kopaonik, pp. 1-4.

Šormaz, G. (2017). Uloga i značaj menadžmenta u obrazovanju. Ekonomija, teorija i praksa. 10(4), pp. 19-32, Novi
Sad: Univerzitet Privredna akademija, Fakultet za ekonomiju i inženjerski menadžment.

Tančić, Lj. (2018). Upravljanje promenama u visokoškolskoj nastavi. XXII Međunarodni kongres iz upravljanja projektima, Zbornik radova Poslovna agilnost $i$ agilno upravljanje projektima, pp. 203-209.

Filipović, M. (2018). Ekološko obrazovanje u funkciji proekološkog ponašanja. Bezbednost. 60(1), pp. 99-111.

Filipović, M. (2019). Konceptualizacija održivog razvoja i ekološko obrazovanje. Vojno delo. 2, pp. 55-68. 